\title{
Physiological cost and drudgery in paddy transplanting
}

\author{
V.V. AWARE, C.R .KAVITKAR, M.R. PATIL, P.U. SHAHARE, S.V. AWARE AND N.A. SHIRSAT
}

Received : 28.02.2017; Revised : 21.03.2017; Accepted : 30.03 .2017

See end of the Paper for authors' affiliation

Correspondence to :

\section{V.V. AWARE}

College of Agricultural Engineering and Technology, Dr. B.S. Konkan Krishi Vidyapeeth, Dapoli, RATNAGIRI (M.S.) INDIA
-ABSTRACT : The field experiment was conducted at agronomy field DBSKKV, Dapoli, on the traditional method of paddy transplanting and manual paddy transplanter. Eight male and seven female workers were participated in this activity. The mean working heart rate (WHR) during traditional method of paddy transplanting for male and female subject were $105.9( \pm 4.01)$ and 106.97 ( \pm 3.39$) \mathrm{bpm}$, respectively, While mean WHR for male workers with manual paddy transplanter was $128.44( \pm 12.38) \mathrm{bpm}$. The field capacity for traditional method of paddy transplanting for male and female workers were $0.0040 \mathrm{ha} / \mathrm{h}\left(40 \mathrm{~m}^{2} / \mathrm{h}\right)$ and $0.0038 \mathrm{ha} / \mathrm{h}\left(38 \mathrm{~m}^{2} / \mathrm{h}\right)$, respectively. The workloads for male and female workers was "Moderately heavy" for traditional method of paddy transplanting. The field capacity and field efficiency with manual paddy transplanter were $0.020 \mathrm{ha} / \mathrm{h}$ and 47.75 per cent, respectively, with 21(DAS) nursery. The workload was "heavy" for manual paddy transplanter. Hence, the field capacity with manual paddy transplanter was 5 times more as compared to traditional method of transplanting. The working heart rate (WHR) with manual paddy transplanter for male workers was 0.82 more as compared to traditional paddy transplanting.

- KEY WORDS : Physiological cost, Drudgery, Paddy transplanting, Manual paddy transplanter, BPDS, ODR

- HOW TO CITE THIS PAPER : Aware, V.V., Kavitkar, C.R., Patil, M.R., Shahare, P.U., Aware, S.V. and Shirsat, N.A. (2017). Physiological cost and drudgery in paddy transplanting. Internat. J. Agric. Engg., 10(1) : 208-213, DOI: 10.15740/HAS/IJAE/10.1/208-213. 